\title{
OPEN Agreement of different OCT scan directions for individual retinal-layer thickness measurements in multiple sclerosis subjects with prior unilateral optic neuritis
}

\begin{abstract}
Alberto Domínguez-Vicent ${ }^{\bowtie}$, Maria Nilsson, Rune Brautaset \& Abinaya Priya Venkataraman
The similarities between horizontal and vertical Optical Coherence Tomography (OCT) scans for the individual retinal layer thickness measurements in the macula was evaluated. Two volumetric scans (B-scans oriented horizontally and vertically) were performed in 64 multiple sclerosis subjects with history of unilateral optic neuritis and 64 healthy controls. The agreement between the thickness measurements with horizontal and vertical OCT scans was evaluated in 3 groups of eyes: healthy controls, eyes with history of optic neuritis and the fellow eyes. The mean difference in individual layer thickness between the scans was smaller than the instrument's axial resolution in all 3 groups. The limit of agreement (LoA) varied among the different layers and sectors analyzed and this trend was similar in all the groups. For the inner retinal layers (retinal nerve fiber layer to inner nuclear layer), the inner macular sectors had a larger LoA compared to the corresponding outer sectors. In the outer plexiform and nuclear layers, the central and inner sectors (except inner temporal) had LoA larger than the other sectors and layers. The larger LoA seen for different layers and sectors suggests that the scan direction must be same for the follow-up OCT measurements and in clinical studies.
\end{abstract}

Macular volumetric measurements using Optical Coherence Tomography (OCT) plays an important role in the diagnosis and follow up of various ocular and neurological disorders ${ }^{1-4}$. The OCTs that are clinically available are incorporated with their own segmentation algorithm which provides data of the total retinal thickness and individual layer thickness of ganglion cell layer (GCL), inner plexiform layer (IPL) and retinal nerve fiber layer (RNFL). Recent developments in instrumentation and image analysis algorithms allow further segmentation of individual layers, which is of great use in different areas in ophthalmology and neurology $y^{5-7}$.

The automated segmentation algorithm's reliability for thickness measurement of RNFL, GCL and IPL have been widely studied in the past and are shown to be clinically acceptable ${ }^{8-11}$. Changes in these layers are shown to be a hallmark in the diagnosis of glaucoma ${ }^{12-15}$. The changes in the thickness of the inner retinal layers are reported in different neurologic disorders including multiple sclerosis ${ }^{16,17}$ and Parkinson's disease ${ }^{18,19}$. In multiple sclerosis subjects, the retinal morphological changes are limited to the inner retinal layers in the absence of optic neuritis or when there is a good visual acuity recovery following optic neuritis; in the presence of optic neuritis with poor visual recovery, the changes can be seen in both inner and outer retinal layers can be seen. Another study has also shown that there are changes in the outer nuclear layer (ONL) that reverts to the baseline in eyes with optic neuritis ${ }^{20}$.

The reliability of the thickness measurements depends on various factors like scan resolution, acquisition time, segmentation algorithm and the retinal condition ${ }^{8,9,21-23}$. The scan direction is also shown to affect the precision of the quantitative measurements in both macula and optic disc ${ }^{7,10,24}$. For the total retinal measurements in the macular region, the horizontally oriented B-scans showed better repeatability for nasal and temporal sectors and the vertical scans showed better repeatability for superior and inferior sectors in healthy eyes ${ }^{10}$. For the 
A
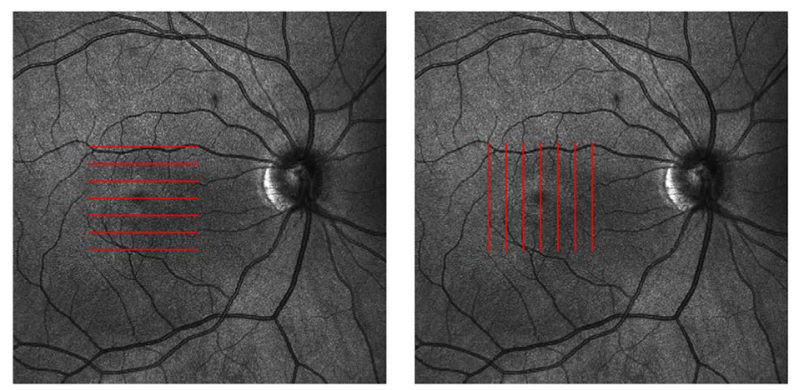

B
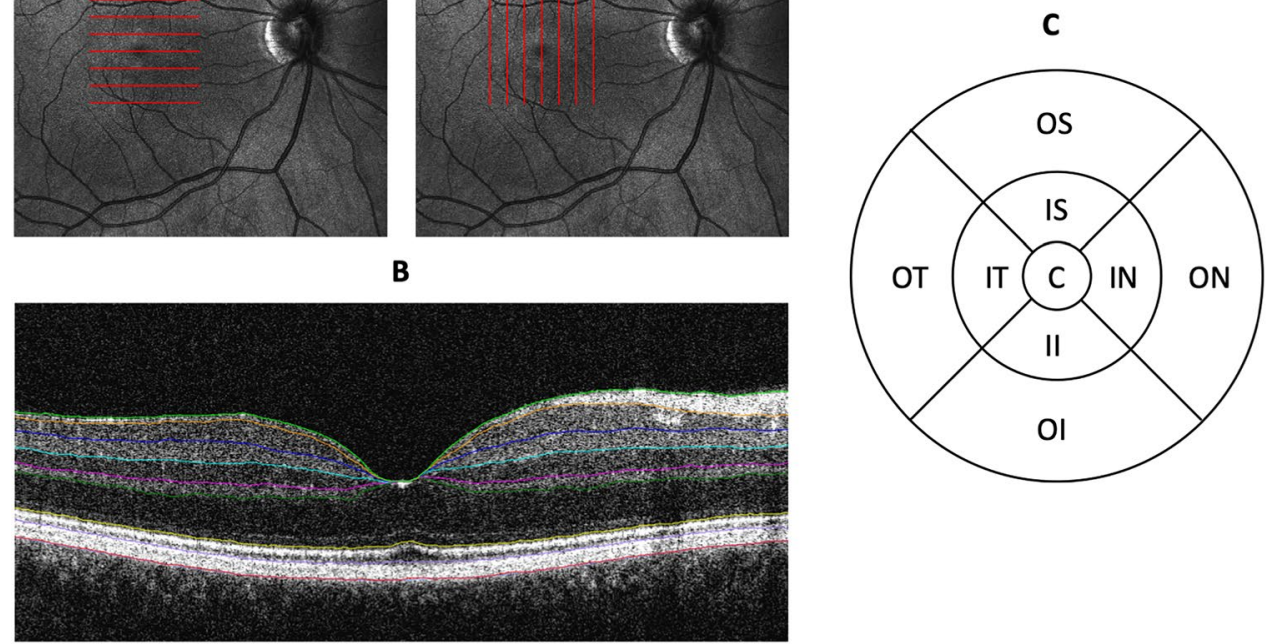

Figure 1. Macular volumetric OCT measurements. (A) Schematic representation of the B-scan orientation used in the macular volumetric measurements in the right eye. (B) An example B-scan showing the individual retinal layer segmentation. (C) Schematic representation of the ETDRS sectors. $C$ central circle, II inner inferior, OI outer inferior, IN inner nasal, ON outer nasal, IS inner superior, OS outer superior, IT inner temporal, OT outer temporal sectors.

peripapillary RNFL measurements, similar trend was reported in healthy eyes ${ }^{24}$. The similarities in the retinal layer thickness measurement between different scan directions were also evaluated in healthy subjects and similar results have been reported in a small cohort of multiple sclerosis subjects.

The variations in the individual retinal layer thickness measurement with different scan directions in multiple sclerosis subjects with history of optic neuritis could be different from healthy controls as the retinal morphology is different between the groups. In order to evaluate this, we included multiple sclerosis subjects with unilateral optic neuritis in the present study, so that the variations in the fellow eye can also be studied. The agreement between the measurement of individual retinal layer thickness with the two scan directions are evaluated in 3 sub-groups: healthy controls, eyes with a history of optic neuritis and the fellow eyes.

\section{Methods}

Subjects. OCT measurement data from 64 multiple sclerosis subjects with history of unilateral optic neuritis was retrieved for this study. All subjects were measured at the Neurology Clinic, Neuro Centrum at Karolinska University Hospital, Solna, Sweden. Subjects with acute optic neuritis within 6 months before the OCT measurements were excluded. Subjects with any other neurologic or ocular diseases that could influence the outcome measures were excluded. 64 age matched healthy controls were also included in this study. The study design followed the Declaration of Helsinki principles and was approved by the the Regional Ethical Committee (Regionala etikpröningsnämden, Stockholm 2011/874-31/2). Informed consents were obtained from all participants.

OCT measurements. All subjects underwent OCT examination using the Canon OCT HS-100 (Canon Europe, Netherlands) which performs up to 70,000 A-scans/second with an axial resolution of $3 \mu \mathrm{m}$. For the multiple sclerosis subjects, both eyes were included: eye with history of optic neuritis (ON), and the fellow eye with no history of optic neuritis (NON). For the healthy controls (HC), only one eye was included (33 right eyes and 31 left eyes). Two macular volumetric scans were performed with a scan area of $10 \times 10 \mathrm{~mm}$ containing 128 B-scans each consisting of 1,024 A-scans. One volumetric scan had the B-scans oriented in horizontal direction and the other had the B-scans oriented in vertical direction (Fig. 1A). Only scans with signal strength of 7 or higher were included.

The automated segmentation software (version 4.5) of the instrument was used to delineate 8 different layers of the retina (Fig. 1B): RNFL, GCL, IPL, Inner Nuclear Layer (INL), Outer Plexiform Layer (OPL), ONL, Outer Segment (OS) and Retinal Pigment Epithelium (RPE). No manual adjustment of the segmentation was performed. The thickness of each layer specified above was evaluated in 9 sectors centered in the fovea based on Early Treatment Diabetic Retinopathy Study (ETDRS) protocol with the central circle, inner ring (Superior, Nasal, Inferior and temporal), and outer ring (Superior, Nasal, Inferior and temporal) with diameter of 1, 3, and $6 \mathrm{~mm}$ respectively (Fig. 1C). 


\begin{tabular}{|c|c|c|c|c|c|c|c|c|c|c|c|c|c|c|c|c|c|c|c|}
\hline \multirow{2}{*}{$\begin{array}{l}\text { Retinal } \\
\text { layer }\end{array}$} & \multirow[b]{2}{*}{ Eyes } & \multicolumn{2}{|l|}{ Central } & \multicolumn{2}{|c|}{ Inner inferior } & \multicolumn{2}{|c|}{ Outer inferior } & \multicolumn{2}{|l|}{ Inner nasal } & \multicolumn{2}{|l|}{ Outer nasal } & \multicolumn{2}{|c|}{ Inner superior } & \multicolumn{2}{|c|}{ Outer superior } & \multicolumn{2}{|c|}{ Inner temporal } & \multicolumn{2}{|c|}{ Outer temporal } \\
\hline & & $\mathbf{H}$ & v & $\mathbf{H}$ & $\mathrm{v}$ & $\mathbf{H}$ & v & $\mathbf{H}$ & V & $\mathbf{H}$ & $\mathbf{v}$ & $\mathrm{H}$ & $\mathrm{V}$ & $\mathbf{H}$ & $\mathrm{v}$ & $\mathbf{H}$ & $\mathrm{v}$ & $\mathbf{H}$ & $\mathrm{v}$ \\
\hline \multirow{3}{*}{ RNFL } & $\mathrm{HC}$ & $8.9 \pm 2.0$ & $8.8 \pm 1.8$ & $26.1 \pm 3.8$ & $26.7 \pm 3.3$ & $40.0 \pm 6.8$ & $40.2 \pm 6.6$ & $21.2 \pm 2.5$ & $20.5 \pm 2.2$ & $48.3 \pm 7.4$ & $48.6 \pm 7.5$ & $24.7 \pm 3.1$ & $24.7 \pm 3.1$ & $38.4 \pm 5.9$ & $37.9 \pm 6.0$ & $17.2 \pm 1.3$ & $16.8 \pm 1.6$ & $18.3 \pm 1.4$ & $18.3 \pm 1.6$ \\
\hline & $\mathrm{ON}$ & $9.7 \pm 3.5$ & $9.6 \pm 2.6$ & $20.3 \pm 3.4$ & $21.3 \pm 3.9$ & $29.9 \pm 7.6$ & $30.3 \pm 7.8$ & $19.0 \pm 3.6$ & $18.3 \pm 2.4$ & $36.3 \pm 9.0$ & $36.0 \pm 8.7$ & $20.4 \pm 3.3$ & $20.7 \pm 3.3$ & $29.1 \pm 6.5$ & $29.2 \pm 6.5$ & $17.1 \pm 2.9$ & $16.5 \pm 2.1$ & $17.5 \pm 1.9$ & $17.4 \pm 1.8$ \\
\hline & NON & $8.9 \pm 2.0$ & $9.4 \pm 1.9$ & $23.5 \pm 3.8$ & $24.4 \pm 3.7$ & $35.5 \pm 7.3$ & $35.8 \pm 7.1$ & $20.7 \pm 3.5$ & $20.1 \pm 2.9$ & $42.6 \pm 8.6$ & $42.5 \pm 9.4$ & $22.6 \pm 3.7$ & $23.1 \pm 3.6$ & $34.0 \pm 6.4$ & $33.8 \pm 6.2$ & $17.4 \pm 1.6$ & $17.0 \pm 1.8$ & $18.3 \pm 1.9$ & $18.2 \pm 2.4$ \\
\hline \multirow{3}{*}{ GCL } & $\mathrm{HC}$ & $16.7 \pm 5.1$ & $16.6 \pm 4.6$ & $50.9 \pm 5.3$ & $50.5 \pm 5.4$ & $28.0 \pm 3.1$ & $27.7 \pm 2.8$ & $51.6 \pm 5.7$ & $51.8 \pm 5.8$ & $34.2 \pm 4.3$ & $34.2 \pm 4.1$ & $52.0 \pm 5.8$ & $51.4 \pm 5.3$ & $29.9 \pm 3.2$ & $30.4 \pm 3.0$ & $48.9 \pm 5.0$ & $48.7 \pm 4.9$ & $32.2 \pm 3.6$ & $31.9 \pm 3.9$ \\
\hline & ON & $13.0 \pm 4.9$ & $13.0 \pm 4.9$ & $36.2 \pm 9.6$ & $35.4 \pm 8.8$ & $24.8 \pm 2.9$ & $24.8 \pm 2.7$ & $36.6 \pm 9.8$ & $36.4 \pm 9.5$ & $27.4 \pm 4.5$ & $27.1 \pm 5.2$ & $36.5 \pm 8.9$ & $36.2 \pm 8.8$ & $25.5 \pm 3.5$ & $25.9 \pm 3.3$ & $33.2 \pm 9.3$ & $33.4 \pm 9.4$ & $26.3 \pm 4.4$ & $26.2 \pm 4.3$ \\
\hline & NON & $15.3 \pm 4.9$ & $15.6 \pm 5.2$ & $43.2 \pm 9.0$ & $42.7 \pm 8.6$ & $26.4 \pm 3.0$ & $26.3 \pm 3.1$ & $43.4 \pm 9.7$ & $43.0 \pm 9.6$ & $29.9 \pm 4.5$ & $29.8 \pm 4.9$ & $43.4 \pm 9.0$ & $43.1 \pm 8.8$ & $27.3 \pm 3.3$ & $27.7 \pm 3.4$ & $41.2 \pm 8.9$ & $41.2 \pm 9.1$ & $29.0 \pm 4.2$ & $28.9 \pm 4.5$ \\
\hline \multirow{3}{*}{ IPL } & $\mathrm{HC}$ & $16.4 \pm 4.2$ & $16.4 \pm 3.9$ & $41.6 \pm 3.8$ & $41.6 \pm 3.3$ & $32.1 \pm 2.9$ & $31.9 \pm 3.0$ & $40.7 \pm 3.4$ & $40.6 \pm 3.3$ & $35.6 \pm 3.2$ & $34.8 \pm 3.2$ & $41.1 \pm 3.2$ & $40.4 \pm 3.3$ & $33.0 \pm 3.0$ & $33.2 \pm 3.1$ & $39.0 \pm 3.6$ & $39.3 \pm 3.8$ & $36.5 \pm 3.3$ & $35.6 \pm 3.2$ \\
\hline & ON & $15.5 \pm 4.8$ & $15.0 \pm 4.1$ & $36.3 \pm 4.8$ & $36.4 \pm 4.8$ & $29.5 \pm 3.1$ & $29.1 \pm 3.2$ & $36.2 \pm 5.0$ & $36.2 \pm 4.7$ & $31.2 \pm 4.2$ & $31.1 \pm 3.9$ & $36.9 \pm 4.8$ & $36.4 \pm 4.3$ & $30.7 \pm 3.2$ & $30.5 \pm 3.2$ & $33.9 \pm 5.2$ & $34.1 \pm 5.0$ & $31.8 \pm 4.2$ & $32.0 \pm 3.9$ \\
\hline & NON & $16.1 \pm 4.1$ & $16.3 \pm 4.0$ & $38.6 \pm 4.8$ & $38.6 \pm 4.8$ & $31.1 \pm 3.4$ & $30.7 \pm 3.6$ & $37.9 \pm 4.6$ & $37.8 \pm 5.2$ & $33.3 \pm 4.6$ & $33.0 \pm 4.5$ & $38.8 \pm 4.6$ & $37.9 \pm 4.5$ & $31.9 \pm 3.3$ & $32.1 \pm 3.3$ & $36.4 \pm 4.8$ & $36.5 \pm 5.1$ & $34.5 \pm 4.1$ & $34.2 \pm 4.2$ \\
\hline \multirow{3}{*}{ INL } & $\mathrm{HC}$ & $17.7 \pm 4.7$ & $17.7 \pm 4.3$ & $43.1 \pm 2.9$ & $43.0 \pm 2.9$ & $32.1 \pm 2.7$ & $31.9 \pm 2.4$ & $43.0 \pm 3.3$ & $43.5 \pm 3.2$ & $35.7 \pm 2.5$ & $35.9 \pm 2.4$ & $43.2 \pm 2.9$ & $43.4 \pm 2.5$ & $33.2 \pm 2.5$ & $33.8 \pm 2.2$ & $40.1 \pm 2.7$ & $40.5 \pm 2.9$ & $35.1 \pm 2.6$ & $35.2 \pm 2.6$ \\
\hline & ON & $18.3 \pm 5.9$ & $17.5 \pm 4.8$ & $42.5 \pm 3.3$ & $42.4 \pm 3.6$ & $31.8 \pm 3.1$ & $31.4 \pm 3.1$ & $42.6 \pm 4.3$ & $43.2 \pm 3.7$ & $34.6 \pm 3.8$ & $34.4 \pm 3.8$ & $43.0 \pm 3.3$ & $42.6 \pm 3.4$ & $32.8 \pm 3.0$ & $33.2 \pm 2.9$ & $39.3 \pm 3.3$ & $39.5 \pm 3.5$ & $34.7 \pm 3.1$ & $34.7 \pm 3.2$ \\
\hline & NON & $18.2 \pm 4.9$ & $18.4 \pm 4.4$ & $43.1 \pm 3.5$ & $43.4 \pm 3.8$ & $32.4 \pm 3.0$ & $32.2 \pm 3.1$ & $43.2 \pm 4.4$ & $43.6 \pm 4.4$ & $35.2 \pm 3.8$ & $35.1 \pm 3.9$ & $43.4 \pm 3.5$ & $43.4 \pm 3.5$ & $33.5 \pm 3.2$ & $33.8 \pm 3.1$ & $40.0 \pm 3.4$ & $40.5 \pm 3.5$ & $35.4 \pm 3.2$ & $35.4 \pm 3.4$ \\
\hline \multirow{3}{*}{ OPL } & $\mathrm{HC}$ & $18.7 \pm 6.1$ & $18.5 \pm 5.9$ & $32.9 \pm 7.0$ & $32.7 \pm 5.5$ & $25.4 \pm 3.0$ & $24.9 \pm 2.4$ & $34.2 \pm 8.7$ & $34.4 \pm 9.0$ & $28.5 \pm 4.5$ & $28.8 \pm 4.6$ & $32.9 \pm 5.9$ & $33.1 \pm 5.3$ & $25.9 \pm 2.9$ & $25.7 \pm 2.7$ & $28.9 \pm 3.4$ & $28.9 \pm 3.3$ & $25.0 \pm 2.2$ & $25.2 \pm 2.2$ \\
\hline & ON & $19.2 \pm 6.4$ & $18.0 \pm 5.8$ & $31.2 \pm 3.9$ & $31.1 \pm 3.5$ & $25.3 \pm 3.0$ & $25.1 \pm 2.8$ & $35.2 \pm 9.3$ & $34.6 \pm 8.6$ & $28.9 \pm 4.6$ & $29.2 \pm 4.8$ & $31.3 \pm 4.7$ & $31.0 \pm 4.4$ & $25.4 \pm 2.6$ & $25.3 \pm 2.4$ & $27.1 \pm 2.2$ & $26.8 \pm 2.2$ & $24.5 \pm 1.8$ & $24.8 \pm 2.2$ \\
\hline & NON & $18.5 \pm 6.1$ & $19.0 \pm 5.6$ & $32.4 \pm 4.8$ & $32.7 \pm 5.9$ & $26.0 \pm 3.2$ & $25.6 \pm 3.3$ & $34.8 \pm 8.0$ & $36.3 \pm 9.1$ & $29.2 \pm 4.5$ & $29.8 \pm 4.7$ & $31.3 \pm 5.1$ & $31.7 \pm 5.7$ & $25.3 \pm 2.3$ & $25.4 \pm 2.6$ & $27.3 \pm 3.1$ & $27.3 \pm 2.9$ & $24.6 \pm 1.6$ & $24.8 \pm 1.6$ \\
\hline \multirow{3}{*}{ ONL } & $\mathrm{HC}$ & $123.3 \pm 9.4$ & $123.5 \pm 9.8$ & $85.4 \pm 10.8$ & $85.3 \pm 10.3$ & $69.7 \pm 6.7$ & $69.9 \pm 6.3$ & $91.9 \pm 12.3$ & $91.7 \pm 12.3$ & $74.4 \pm 7.1$ & $74.3 \pm 7.2$ & $88.2 \pm 11.6$ & $88.8 \pm 11.8$ & $78.6 \pm 6.8$ & $79.0 \pm 7.2$ & $94.5 \pm 9.2$ & $94.1 \pm 8.8$ & $76.9 \pm 6.9$ & $76.6 \pm 7.0$ \\
\hline & ON & $120.4 \pm 12.2$ & $123.3 \pm 9.5$ & $89.4 \pm 10.1$ & $88.8 \pm 9.8$ & $71.8 \pm 6.6$ & $71.6 \pm 6.6$ & $91 \pm 14.7$ & $91.5 \pm 13.3$ & $74.6 \pm 8.5$ & $74.7 \pm 8.4$ & $91.8 \pm 10.8$ & $92.6 \pm 9.9$ & $80.3 \pm 7.0$ & $80.7 \pm 7.0$ & $97.9 \pm 8.2$ & $98.0 \pm 8.0$ & $78.5 \pm 6.7$ & $78.5 \pm 6.5$ \\
\hline & NON & $122.4 \pm 9.3$ & $122.8 \pm 10.1$ & $87.3 \pm 9.7$ & $86.1 \pm 10.7$ & $70.9 \pm 6.7$ & $70.6 \pm 6.8$ & $90.4 \pm 12.3$ & $89.2 \pm 13.1$ & $74.2 \pm 7.6$ & $74.1 \pm 7.8$ & $91.3 \pm 10.0$ & $91.3 \pm 11.1$ & $80.4 \pm 7.0$ & $80.6 \pm 7.3$ & $97.1 \pm 8.4$ & $96.6 \pm 8.5$ & $78.4 \pm 6.2$ & $78.5 \pm 6.2$ \\
\hline \multirow{3}{*}{ os } & $\mathrm{HC}$ & $33.8 \pm 1.7$ & $33.7 \pm 1.6$ & $28.5 \pm 1.7$ & $28.3 \pm 1.7$ & $30.5 \pm 2.6$ & $30.2 \pm 2.7$ & $29.7 \pm 1.5$ & $29.8 \pm 1.7$ & $28.8 \pm 2.3$ & $28.8 \pm 2.4$ & $29.0 \pm 1.7$ & $29.0 \pm 1.6$ & $29.2 \pm 2.7$ & $29.0 \pm 2.6$ & $29.2 \pm 1.4$ & $29.0 \pm 1.5$ & $29.0 \pm 2.6$ & $29.0 \pm 2.6$ \\
\hline & NON & $34.7 \pm 1.5$ & $34.6 \pm 1.5$ & $29.1 \pm 2.1$ & $29.3 \pm 2.0$ & $30.4 \pm 2.2$ & $30.6 \pm 2.2$ & $30.2 \pm 1.6$ & $30.3 \pm 1.8$ & $28.8 \pm 2.1$ & $28.9 \pm 2.0$ & $29.5 \pm 1.8$ & $29.7 \pm 1.8$ & $29.0 \pm 2.3$ & $29.3 \pm 2.1$ & $29.6 \pm 1.7$ & $29.7 \pm 1.6$ & $29.3 \pm 2.7$ & $29.5 \pm 2.6$ \\
\hline & ONL & $34.7 \pm 1.5$ & $34.6 \pm 1.6$ & $29.3 \pm 2.2$ & $29.2 \pm 2.0$ & $30.4 \pm 2.4$ & $30.7 \pm 2.1$ & $30.1 \pm 1.8$ & $30.3 \pm 1.8$ & $28.9 \pm 2.1$ & $28.7 \pm 2.1$ & $29.7 \pm 2.0$ & $29.8 \pm 1.8$ & $29.1 \pm 2.4$ & $28.9 \pm 2.2$ & $29.9 \pm 1.9$ & $29.7 \pm 2.2$ & $29.7 \pm 3.0$ & $29.6 \pm 2.9$ \\
\hline \multirow{3}{*}{ RPE } & $\mathrm{HC}$ & $35.8 \pm 1.9$ & $35.8 \pm 1.6$ & $33.0 \pm 1.9$ & $33.0 \pm 2.0$ & $28.3 \pm 2.8$ & $28.5 \pm 2.8$ & $33.7 \pm 1.8$ & $33.5 \pm 1.9$ & $30.9 \pm 2.5$ & $30.4 \pm 2.9$ & $33.5 \pm 2.0$ & $33.6 \pm 1.9$ & $31.3 \pm 2.8$ & $31.3 \pm 2.8$ & $33.5 \pm 1.9$ & $33.4 \pm 1.9$ & $31.3 \pm 3.0$ & $30.9 \pm 3.0$ \\
\hline & ON & $37.0 \pm 1.3$ & $36.8 \pm 1.4$ & $34.0 \pm 2.4$ & $33.6 \pm 2.5$ & $29.5 \pm 2.5$ & $29.2 \pm 2.1$ & $34.3 \pm 2.0$ & $34.0 \pm 2.0$ & $31.9 \pm 2.8$ & $31.8 \pm 2.9$ & $34.3 \pm 2.3$ & $34.2 \pm 2.3$ & $32.6 \pm 2.7$ & $32.7 \pm 2.5$ & $34.5 \pm 2.1$ & $34.0 \pm 2.2$ & $32.1 \pm 2.9$ & $31.2 \pm 3.0$ \\
\hline & NON & $36.9 \pm 1.5$ & $36.8 \pm 1.4$ & $33.7 \pm 2.5$ & $33.2 \pm 2.6$ & $29.1 \pm 2.4$ & $28.8 \pm 2.3$ & $33.9 \pm 1.8$ & $34.0 \pm 2.2$ & $31.4 \pm 2.4$ & $31.2 \pm 2.6$ & $34.3 \pm 2.3$ & $34.2 \pm 2.3$ & $32.3 \pm 2.6$ & $32.1 \pm 2.4$ & $34.5 \pm 2.3$ & $33.8 \pm 2.1$ & $32.1 \pm 2.9$ & $31.1 \pm 2.9$ \\
\hline
\end{tabular}

Table 1. Average thickness values for eight layers in nine early treatment diabetic retinopathy study sectors for the three groups. All values are expressed in microns. $H C$ healthy controls, $O N$ eyes with optic neuritis, $N O N$ fellow eyes without optic neuritis, $H$ horizontal scan, $V$ vertical scan, $R N F L$ retinal nerve fiber layer, $G C L$ ganglion cell layer, $I P L$ inner plexiform layer, $I N L$ inner nuclear layer, $O P L$ outer plexiform layer, $O N L$ outer nuclear layer, $O S$ outer segment, $R P E$ retinal pigment epithelium.

Statistical analysis. The agreement between macular volumetric measurements obtained from the horizontal and vertical B-scans were evaluated with Bland-Altman analyses for single measurement ${ }^{25}$. The agreement analysis was performed for each of the eight individual retinal layers in each of the nine sectors for the 3 groups ( $\mathrm{HC}, \mathrm{ON}$ and $\mathrm{NON})$.

\section{Results}

The study population includes 64 healthy controls ( 47 females) and 64 multiple sclerosis ( 46 females). The average age of the multiple sclerosis subjects and healthy controls were $44 \pm 10$ and $44 \pm 15$ years respectively. The average disease duration in multiple sclerosis subjects was $14 \pm 8$ years.

The average individual layer thickness in the 9 ETDRS sector for the three groups analyzed are shown in Table 1. The results from the Bland-Altman analyses macular volumetric measurements obtained from the horizontal and vertical B-scans for all the layers in nine ETDRS sectors are shown in Table 2. For the control eyes, the mean difference was less than $1 \mu \mathrm{m}$ for all the layers in all the sectors. For the ON eyes, the mean difference was less than $1.5 \mu \mathrm{m}$ for all the layers in all the sectors except the ONL in the central sector where the difference was $2.89 \mu \mathrm{m}$. For the fellow NON eyes, the mean difference was less than $1.5 \mu \mathrm{m}$ for all the layers in all the sectors.

Figure 2 shows the limits of agreement (LoA) interval for all the layers in nine ETDRS sectors. There were large variations in the agreement among different layers and different sectors.

For the inner retinal layers (RNFL, GCL, IPL and INL), the LOA interval never exceeded $15 \mu \mathrm{m}$. For these layers, the inner sectors had larger LOA interval compared to the respective outer sectors and this tendency was seen in all the groups. The central sectors also had larger LoA interval compared to the outer sectors in all three groups. For the OPL and ONL layers, the variability in LoA interval among the sectors was larger compared to the other layers. The central and inner sectors (except inner temporal) for OPL and ONL had LoA intervals larger than $10 \mu \mathrm{m}$ for all 3 groups. Both OS and RPE had uniform LoA intervals among the sectors in all three groups and the LoA intervals never exceeded $7 \mu \mathrm{m}$.

\section{Discussions}

We evaluated the agreement between two macular volumetric scans for the measurements of individual retinal layer thickness in 3 groups: healthy controls, eyes with history of unilateral optic neuritis in multiple sclerosis subjects and in the fellow eyes. The only difference between the two volumetric scans is the orientation of the B-scan. In all the 3 groups, the mean difference between the horizontal and vertical volumetric scan was smaller than the instrument's axial resolution $(3 \mu \mathrm{m})$ for each of the individual retinal layer measured. There was a wide variation in the LOA interval for different layers and sectors and this variation was seen in all 3 groups. 


\begin{tabular}{|c|c|c|c|c|c|c|c|c|c|c|}
\hline Retinal layer & Eyes & Central & Inner inferior & Outer inferior & Inner nasal & Outer nasal & Inner superior & \begin{tabular}{|l}
$\begin{array}{l}\text { Outer } \\
\text { superior }\end{array}$ \\
\end{tabular} & $\begin{array}{l}\text { Inner } \\
\text { temporal }\end{array}$ & $\begin{array}{l}\text { Outer } \\
\text { temporal }\end{array}$ \\
\hline \multirow{3}{*}{ RNFL } & $\mathrm{HC}$ & $\begin{array}{l}-0.05[-3.55 \text { to } \\
3.453]\end{array}$ & $\begin{array}{l}0.58[-3.08 \text { to } \\
4.24]\end{array}$ & $\begin{array}{l}0.27[-2.62 \text { to } \\
3.131]\end{array}$ & $\begin{array}{l}-0.64[-3.4 \text { to } \\
2.12]\end{array}$ & $\begin{array}{l}0.30[-4.03 \text { to } \\
4.63]\end{array}$ & $\begin{array}{l}-0.06[-3.89 \\
\text { to } 3.76]\end{array}$ & \begin{tabular}{|l}
$-0.44[-3.18$ \\
to 2.31$]$
\end{tabular} & $\begin{array}{l}-0.36[-2.58 \\
\text { to } 1.86]\end{array}$ & $\begin{array}{l}0.06[-1.45 \text { to } \\
1.58]\end{array}$ \\
\hline & ON & $\begin{array}{l}-0.14[-6.52 \\
\text { to } 6.24]\end{array}$ & $\begin{array}{l}1.03[-2.87 \text { to } \\
4.94]\end{array}$ & $\begin{array}{l}0.40[-2.75 \text { to } \\
3.53]\end{array}$ & $\begin{array}{l}-0.72[-7.30 \\
\text { to } 5.87]\end{array}$ & $\begin{array}{l}-0.25[-6.60 \\
\text { to } 6.10]\end{array}$ & $\begin{array}{l}0.33[-2.95 \text { to } \\
3.61]\end{array}$ & $\begin{array}{l}0.08[-2.95 \text { to } \\
3.11]\end{array}$ & $\begin{array}{l}-0.59[-5.48 \\
\text { to } 4.29]\end{array}$ & $\begin{array}{l}-0.14[-2.75 \\
\text { to } 2.47]\end{array}$ \\
\hline & NON & $\begin{array}{l}0.45[-3.57 \text { to } \\
4.48]\end{array}$ & $\begin{array}{l}0.81[-4.15 \text { to } \\
5.77]\end{array}$ & $\begin{array}{l}0.28[-3.34 \text { to } \\
3.90]\end{array}$ & $\begin{array}{l}-0.61[-6.19 \\
\text { to } 4.97]\end{array}$ & $\begin{array}{l}-0.11[-6.95 \\
\text { to } 6.73]\end{array}$ & $\begin{array}{l}0.52[-3.34 \text { to } \\
4.37]\end{array}$ & $\begin{array}{l}-0.25[-3.51 \\
\text { to } 3.01]\end{array}$ & $\begin{array}{l}-0.33[-3.29 \\
\text { to } 2.64]\end{array}$ & $\begin{array}{l}-0.05[-3.24 \\
\text { to } 3.14]\end{array}$ \\
\hline \multirow{3}{*}{ GCL } & $\mathrm{HC}$ & $\begin{array}{l}-0.13[-6.01 \\
\text { to } 5.75]\end{array}$ & $\begin{array}{l}-0.41[-4.72 \\
\text { to } 3.91]\end{array}$ & $\begin{array}{l}-0.30[-3.11 \\
\text { to } 2.51]\end{array}$ & $\begin{array}{l}0.19[-3.34 \text { to } \\
3.71]\end{array}$ & $\begin{array}{l}0.03[-2.7 \text { to } \\
2.8]\end{array}$ & $\begin{array}{l}-0.63[-4.63 \\
\text { to } 3.38]\end{array}$ & $\begin{array}{l}0.53[-2.1 \text { to } \\
3.17]\end{array}$ & $\begin{array}{l}-0.19[-4.26 \\
\text { to } 3.88]\end{array}$ & $\begin{array}{l}-0.23[-2.62 \\
\text { to } 2.15]\end{array}$ \\
\hline & ON & $\begin{array}{l}-0.03[-5.16 \\
\text { to } 5.10]\end{array}$ & \begin{tabular}{|l|}
$-0.81[-5.40$ \\
to 3.78$]$
\end{tabular} & $\begin{array}{l}0.03[-1.91 \text { to } \\
1.98]\end{array}$ & $\begin{array}{l}-0.23[-4.58 \\
\text { to } 4.11]\end{array}$ & $\begin{array}{l}-0.23[-3.27 \\
\text { to } 2.81]\end{array}$ & $\begin{array}{l}-0.25[-3.62 \\
\text { to } 3.12]\end{array}$ & $\begin{array}{l}0.41[-1.49 \text { to } \\
2.31]\end{array}$ & $\begin{array}{l}0.23[-3.74 \text { to } \\
4.21]\end{array}$ & $\begin{array}{l}-0.09[-2.63 \\
\text { to } 2.44]\end{array}$ \\
\hline & NON & $\begin{array}{l}0.31[-4.01 \text { to } \\
4.63]\end{array}$ & \begin{tabular}{|l|}
$-0.48[-3.94$ \\
to 2.97$]$
\end{tabular} & $\begin{array}{l}-0.14[-2.14 \\
\text { to } 1.86]\end{array}$ & $\begin{array}{l}-0.41[-4.92 \\
\text { to } 4.10]\end{array}$ & $\begin{array}{l}-0.09[-3.36 \\
\text { to } 3.18]\end{array}$ & $\begin{array}{l}-0.31[-3.49 \\
\text { to } 2.87]\end{array}$ & $\begin{array}{l}0.36[-1.69 \text { to } \\
2.41]\end{array}$ & $\begin{array}{l}0.03[-3.81 \text { to } \\
3.87]\end{array}$ & $\begin{array}{l}-0.06[-3.55 \\
\text { to } 3.43]\end{array}$ \\
\hline \multirow{3}{*}{ IPL } & $\mathrm{HC}$ & $\begin{array}{l}-0.03[-4.65 \\
\text { to } 4.59]\end{array}$ & $\begin{array}{l}-0.06[-4.41 \\
\text { to } 4.28]\end{array}$ & $\begin{array}{l}-0.25[-2.54 \\
\text { to } 2.04]\end{array}$ & $\begin{array}{l}-0.11[-3.72 \\
\text { to } 3.51]\end{array}$ & $\begin{array}{l}-0.81[-3.23 \\
\text { to } 1.60]\end{array}$ & $\begin{array}{l}-0.64[-4.31 \\
\text { to } 3.02]\end{array}$ & $\begin{array}{l}0.266[-2 \text { to } \\
2.54]\end{array}$ & $\begin{array}{l}0.328[-3.34 \\
\text { to } 4.00]\end{array}$ & $\begin{array}{l}-0.86[-2.83 \\
\text { to } 1.11]\end{array}$ \\
\hline & ON & $\begin{array}{l}-0.45[-5.47 \\
\text { to } 4.57]\end{array}$ & $\begin{array}{l}0.09[-3.01 \text { to } \\
3.19]\end{array}$ & $\begin{array}{l}-0.38[-2.49 \mathrm{o} \\
1.74]\end{array}$ & $\begin{array}{l}0.00[-3.78 \text { to } \\
-3.78]\end{array}$ & $\begin{array}{l}-0.09[-2.79 \\
\text { to } 2.61]\end{array}$ & $\begin{array}{l}-0.48[-3.57 \\
\text { to } 2.60]\end{array}$ & $\begin{array}{l}-0.16[-2.13 \\
\text { to } 1.83]\end{array}$ & $\begin{array}{l}0.20[-3.72 \text { to } \\
4.13]\end{array}$ & $\begin{array}{l}0.19[-2.30 \text { to } \\
2.68]\end{array}$ \\
\hline & NON & $\begin{array}{l}0.19[-3.70 \text { to } \\
4.07]\end{array}$ & $\begin{array}{l}-0.02[-3.96 \\
\text { to } 3.93]\end{array}$ & $\begin{array}{l}-0.44[-2.72 \\
\text { to } 1.85]\end{array}$ & $\begin{array}{l}-0.11[-3.89 \\
\text { to } 3.67]\end{array}$ & $\begin{array}{l}-0.23[-3.15 \\
\text { to } 2.68]\end{array}$ & $\begin{array}{l}-0.95[-4.64 \\
\text { to } 2.73]\end{array}$ & $\begin{array}{l}0.17[-1.63 \text { to } \\
1.97]\end{array}$ & $\begin{array}{l}0.08[-3.30 \text { to } \\
3.45]\end{array}$ & $\begin{array}{l}-0.34[-3.43 \\
\text { to } 2.74]\end{array}$ \\
\hline \multirow{3}{*}{ INL } & $\mathrm{HC}$ & $\begin{array}{l}0.02[-4.82 \text { to } \\
4.85]\end{array}$ & $\begin{array}{l}-0.03[-3.13 \\
\text { to } 3.07]\end{array}$ & $\begin{array}{l}-0.22[-2.62 \\
\text { to } 2.187]\end{array}$ & $\begin{array}{l}0.50[-2.09 \text { to } \\
3.09]\end{array}$ & $\begin{array}{l}0.23[-1.39 \text { to } \\
1.86]\end{array}$ & $\begin{array}{l}0.27[-2.49 \text { to } \\
3.02]\end{array}$ & $\begin{array}{l}0.66[-1.36 \text { to } \\
2.80]\end{array}$ & $\begin{array}{l}0.42[-2.39 \text { to } \\
3.23]\end{array}$ & $\begin{array}{l}0.09[-1.61 \text { to } \\
1.79]\end{array}$ \\
\hline & ON & $\begin{array}{l}-0.81[-6.63 \\
\text { to } 5.01]\end{array}$ & $\begin{array}{l}-0.19[-3.04 \\
\text { to } 2.67]\end{array}$ & $\begin{array}{l}-0.39[-2.16 \\
\text { to } 1.38]\end{array}$ & $\begin{array}{l}0.56[-4.08 \text { to } \\
5.21]\end{array}$ & $\begin{array}{l}-0.17[-2.84 \\
\text { to } 2.50]\end{array}$ & $\begin{array}{l}-0.38[-2.34 \\
\text { to } 1.59]\end{array}$ & $\begin{array}{l}0.34[-1.58 \text { to } \\
2.26]\end{array}$ & $\begin{array}{l}0.19[-2.85 \text { to } \\
3.23]\end{array}$ & $\begin{array}{l}0.02[-2.96 \text { to } \\
2.99]\end{array}$ \\
\hline & NON & $\begin{array}{l}0.16[-4.56 \text { to } \\
4.87]\end{array}$ & $\begin{array}{l}0.28[-3.29 \text { to } \\
3.85]\end{array}$ & $\begin{array}{l}-0.23[-2.14 \\
\text { to } 1.67]\end{array}$ & $\begin{array}{l}0.39[-3.84 \text { to } \\
4.62]\end{array}$ & $\begin{array}{l}-0.09[2.34 \text { to } \\
-2.53]\end{array}$ & $\begin{array}{l}-0.05[-2.91 \\
\text { to } 2.82]\end{array}$ & $\begin{array}{l}0.27[1.84 \text { to } \\
-1.31]\end{array}$ & $\begin{array}{l}0.48[-2.48 \text { to } \\
3.45]\end{array}$ & $\begin{array}{l}-0.06[-2.06 \\
\text { to } 1.94]\end{array}$ \\
\hline \multirow{3}{*}{ OPL } & $\mathrm{HC}$ & $\begin{array}{l}-0.20[-6.15 \\
\text { to } 5.75]\end{array}$ & $\begin{array}{l}-0.20[-10.2 \\
\text { to } 9.81]\end{array}$ & $\begin{array}{l}-0.50[-4.24 \\
\text { to } 3.25]\end{array}$ & $\begin{array}{l}0.19[-7.73 \text { to } \\
7.10]\end{array}$ & $\begin{array}{l}0.28[-2.97 \text { to } \\
3.53]\end{array}$ & $\begin{array}{l}0.188[-9.93 \\
\text { to } 10.3]\end{array}$ & $\begin{array}{l}-0.13[-4.58 \\
\text { to } 4.32]\end{array}$ & \begin{tabular}{|l|}
$0.02[-4.54$ to \\
$4.576]$ \\
\end{tabular} & $\begin{array}{l}0.25[-2.07 \text { to } \\
2.56]\end{array}$ \\
\hline & ON & \begin{tabular}{|l}
$-1.20[-7.21$ \\
to 4.81$]$
\end{tabular} & $\begin{array}{l}-0.08[-4.43 \\
\text { to } 4.27]\end{array}$ & $\begin{array}{l}-0.28[-2.91 \\
\text { to } 2.34]\end{array}$ & $\begin{array}{l}-0.56[-9.91 \\
\text { to } 8.78]\end{array}$ & $\begin{array}{l}0.34[-2.92 \text { to } \\
3.61]\end{array}$ & $\begin{array}{l}-0.33[-7.52 \\
\text { to } 6.86]\end{array}$ & $\begin{array}{l}-0.13[-3.08 \\
\text { to } 2.83]\end{array}$ & $\begin{array}{l}-0.25[-2.82 \\
\text { to } 2.32]\end{array}$ & $\begin{array}{l}0.29[-2.72 \text { to } \\
3.32]\end{array}$ \\
\hline & NON & $\begin{array}{l}0.48[-9.59 \text { to } \\
10.56]\end{array}$ & $\begin{array}{l}0.34[-7.62 \text { to } \\
8.31]\end{array}$ & $\begin{array}{l}-0.34[-3.12 \\
\text { to } 2.43]\end{array}$ & $\begin{array}{l}1.44[-8.60 \text { to } \\
11.48]\end{array}$ & $\begin{array}{l}0.61[-2.98 \text { to } \\
4.20]\end{array}$ & $\begin{array}{l}0.41[-9.79 \text { to } \\
10.60]\end{array}$ & $\begin{array}{l}0.03[-3.46 \text { to } \\
3.52]\end{array}$ & $\begin{array}{l}0.02[-3.66 \text { to } \\
3.69]\end{array}$ & $\begin{array}{l}0.20[-2.06 \text { to } \\
2.47]\end{array}$ \\
\hline \multirow{3}{*}{ ONL } & $\mathrm{HC}$ & $\begin{array}{l}0.20[-12.10 \\
\text { to } 12.55]\end{array}$ & $\begin{array}{l}-0.08[-11.7 \\
\text { to } 11.5]\end{array}$ & $\begin{array}{l}0.20[-4.18 \text { to } \\
4.58]\end{array}$ & $\begin{array}{l}-0.14[-8.32 \\
\text { to } 8.04]\end{array}$ & $\begin{array}{l}-0.09[-4.16 \\
\text { to } 3.98]\end{array}$ & $\begin{array}{l}0.67[-11.6 \text { to } \\
12.92]\end{array}$ & $\begin{array}{l}0.39[-4.65 \text { to } \\
5.44]\end{array}$ & $\begin{array}{l}-0.44[-5.91 \\
\text { to } 5.04]\end{array}$ & $\begin{array}{l}-0.3[-2.73 \text { to } \\
2.14]\end{array}$ \\
\hline & ON & \begin{tabular}{|l|}
$2.89[-13.43$ \\
to 19.21$]$
\end{tabular} & $\begin{array}{l}-0.55[-6.79 \\
\text { to } 5.70]\end{array}$ & $\begin{array}{l}-0.19[-2.98 \\
\text { to } 2.60]\end{array}$ & $\begin{array}{l}0.47[-10.12 \text { to } \\
11.06]\end{array}$ & \begin{tabular}{|l}
$0.13[-3.48$ to \\
$3.73]$
\end{tabular} & $\begin{array}{l}0.88[-7.17 \text { to } \\
8.92]\end{array}$ & \begin{tabular}{|l}
$0.45[-2.43$ to \\
$3.33]$
\end{tabular} & $\begin{array}{l}0.06[-4.27 \text { to } \\
4.39]\end{array}$ & $\begin{array}{l}0.02[-3.38 \text { to } \\
3.41]\end{array}$ \\
\hline & NON & $\begin{array}{l}0.38[-16.46 \\
\text { to } 17.21]\end{array}$ & $\begin{array}{l}-1.16[-11.42 \\
\text { to } 9.10]\end{array}$ & $\begin{array}{l}-0.30[-3.71 \\
\text { to } 3.12]\end{array}$ & $\begin{array}{l}-1.20[-13.92 \\
\text { to } 11.51]\end{array}$ & $\begin{array}{l}-0.14[-3.82 \\
\text { to } 3.54]\end{array}$ & $\begin{array}{l}0.08[-13.01 \\
\text { to } 13.17]\end{array}$ & $\begin{array}{l}0.23[-3.86 \text { to } \\
4.33]\end{array}$ & $\begin{array}{l}-0.47[-5.05 \\
\text { to } 4.11]\end{array}$ & $\begin{array}{l}0.13[-1.93 \text { to } \\
2.18]\end{array}$ \\
\hline \multirow{3}{*}{ OS } & $\mathrm{HC}$ & $\begin{array}{l}-0.11[-1.55 \\
\text { to } 1.34]\end{array}$ & $\begin{array}{l}-0.19[-2.36 \\
\text { to } 1.99]\end{array}$ & $\begin{array}{l}-0.30[-2.50 \\
\text { to } 1.90]\end{array}$ & $\begin{array}{l}0.04[-1.88 \text { to } \\
1.97]\end{array}$ & $\begin{array}{l}0.06[-3.15 \text { to } \\
3.28]\end{array}$ & $\begin{array}{l}0.03[-2.00 \text { to } \\
2.67]\end{array}$ & \begin{tabular}{|l}
$-0.14[-2.45$ \\
to 2.17$]$
\end{tabular} & $\begin{array}{l}-0.25[-1.85 \\
\text { to } 1.35]\end{array}$ & $\begin{array}{l}-0.06[-3.10 \\
\text { to } 2.97]\end{array}$ \\
\hline & NON & $\begin{array}{l}-0.11[-1.93 \\
\text { to } 1.71]\end{array}$ & $\begin{array}{l}-0.03[-1.85 \\
\text { to } 1.78]\end{array}$ & $\begin{array}{l}0.28[-1.99 \text { to } \\
2.56]\end{array}$ & $\begin{array}{l}0.11[-1.90 \text { to } \\
2.12]\end{array}$ & $\begin{array}{l}-0.14[-1.92 \\
\text { to } 1.64]\end{array}$ & $\begin{array}{l}0.09[-1.75 \text { to } \\
1.93]\end{array}$ & $\begin{array}{l}-0.19[-2.06 \\
\text { to } 1.69]\end{array}$ & $\begin{array}{l}-0.17[-2.13 \\
\text { to } 1.79]\end{array}$ & $\begin{array}{l}-0.17[-2.42 \\
\text { to } 2.08]\end{array}$ \\
\hline & ONL & $\begin{array}{l}-0.06[-2.30 \\
\text { to } 2.17]\end{array}$ & $\begin{array}{l}0.19[-2.87 \text { to } \\
3.25]\end{array}$ & $\begin{array}{l}0.22[-1.83 \text { to } \\
2.27]\end{array}$ & $\begin{array}{l}0.09[-2.84 \text { to } \\
3.03]\end{array}$ & $\begin{array}{l}0.16[-2.19 \text { to } \\
2.50]\end{array}$ & $\begin{array}{l}0.16[-2.17 \text { to } \\
2.48]\end{array}$ & $\begin{array}{l}0.36[-2.57 \text { to } \\
3.29]\end{array}$ & $\begin{array}{l}0.05[-2.12 \text { to } \\
2.21]\end{array}$ & $\begin{array}{l}0.17[-3.15 \text { to } \\
3.50]\end{array}$ \\
\hline \multirow{3}{*}{ RPE } & $\mathrm{HC}$ & $\begin{array}{l}0.02[-2.15 \text { to } \\
2.18]\end{array}$ & $\begin{array}{l}-0.02[-2.10 \\
\text { to } 2.07]\end{array}$ & $\begin{array}{l}0.25[-2.20 \text { to } \\
2.70]\end{array}$ & $\begin{array}{l}-0.17[-1.97 \\
\text { to } 1.63]\end{array}$ & $\begin{array}{l}-0.45[-3.04 \\
\text { to } 2.14]\end{array}$ & $\begin{array}{l}0.05[-2.25 \text { to } \\
2.35]\end{array}$ & $\begin{array}{l}-0.03[-2.40 \\
\text { to } 2.34]\end{array}$ & $\begin{array}{l}-0.09[-2.29 \\
\text { to } 2.11]\end{array}$ & $\begin{array}{l}-0.42[-3.30 \\
\text { to } 2.45]\end{array}$ \\
\hline & ON & $\begin{array}{l}-0.27[-1.84 \\
\text { to } 1.31]\end{array}$ & $\begin{array}{l}-0.38[-2.14 \\
\text { to } 1.39]\end{array}$ & $\begin{array}{l}-0.31[-2.65 \\
\text { to } 2.03]\end{array}$ & $\begin{array}{l}-0.20[-2.30 \\
\text { to } 1.89]\end{array}$ & $\begin{array}{l}-0.17[-2.23 \\
\text { to } 1.88]\end{array}$ & $\begin{array}{l}-0.13[-1.92 \\
\text { to } 1.67]\end{array}$ & $\begin{array}{l}0.06[-2.20 \text { to } \\
2.32]\end{array}$ & $\begin{array}{l}-0.56[-2.37 \\
\text { to } 1.25]\end{array}$ & $\begin{array}{l}-0.95[-3.20 \\
t 1.29]\end{array}$ \\
\hline & NON & $\begin{array}{l}-0.16[-2.43 \\
\text { to } 2.11]\end{array}$ & $\begin{array}{l}-0.48[-3.72 \\
\text { to } 2.75]\end{array}$ & $\begin{array}{l}-0.27[-2.59 \\
\text { to } 2.06]\end{array}$ & $\begin{array}{l}0.13[-2.26 \text { to } \\
2.51]\end{array}$ & $\begin{array}{l}-0.20[-2.63 \\
\text { to } 2.22]\end{array}$ & $\begin{array}{l}-0.03[-2.15 \\
\text { to } 2.09]\end{array}$ & $\begin{array}{l}-0.25[-3.43 \\
\text { to } 2.93]\end{array}$ & $\begin{array}{l}-0.63[-3.06 \\
\text { to } 1.81]\end{array}$ & $\begin{array}{l}-1.03[-4.42 \\
\text { to } 2.35]\end{array}$ \\
\hline
\end{tabular}

Table 2. Bland-Altmann analysis results. Mean difference and limits of agreement for the horizontal and vertical scans. All values are expressed in microns. $H C$ healthy controls, $O N$ eyes with optic neuritis, NON fellow eyes without optic neuritis, RNFL retinal nerve fiber layer, GCL ganglion cell layer, IPL inner plexiform layer, $I N L$ inner nuclear layer, $O P L$ outer plexiform layer, $O N L$ outer nuclear layer, $O S$ outer segment, $R P E$ retinal pigment epithelium.

The reduction of around $15 \mu \mathrm{m}$ in average macular RNFL thickness and GCL-IPL thickness were reported in eyes with prior optic neuritis in multiple sclerosis subjects compared to healthy controls ${ }^{26,27}$. The present results show that the measurements of these layers with two different scan modes can differ up to $11 \mu \mathrm{m}$ and $14 \mu \mathrm{m}$ in the HC and multiple sclerosis subjects respectively, in some of the ETDRS sectors. This suggests that we cannot interchange the volumetric measurements from the horizontal and vertical scans. It has been reported that the reduction in GCL-IPL thickness in multiple sclerosis subjects with prior optic neuritis follows a horseshoe-like thickness reduction pattern corresponding to inner sectors (except inner temporal) ${ }^{26}$. These are the sectors that had larger differences between the horizontal and vertical scanning modes in the present study. This finding can also be interesting in the diagnosis and follow up of glaucoma which also causes macular RNFL, GCL and IPL reduction ${ }^{14,15}$. It can be suggested that the scan direction should be considered for both clinical follow up and for comparison of results from different research studies. 

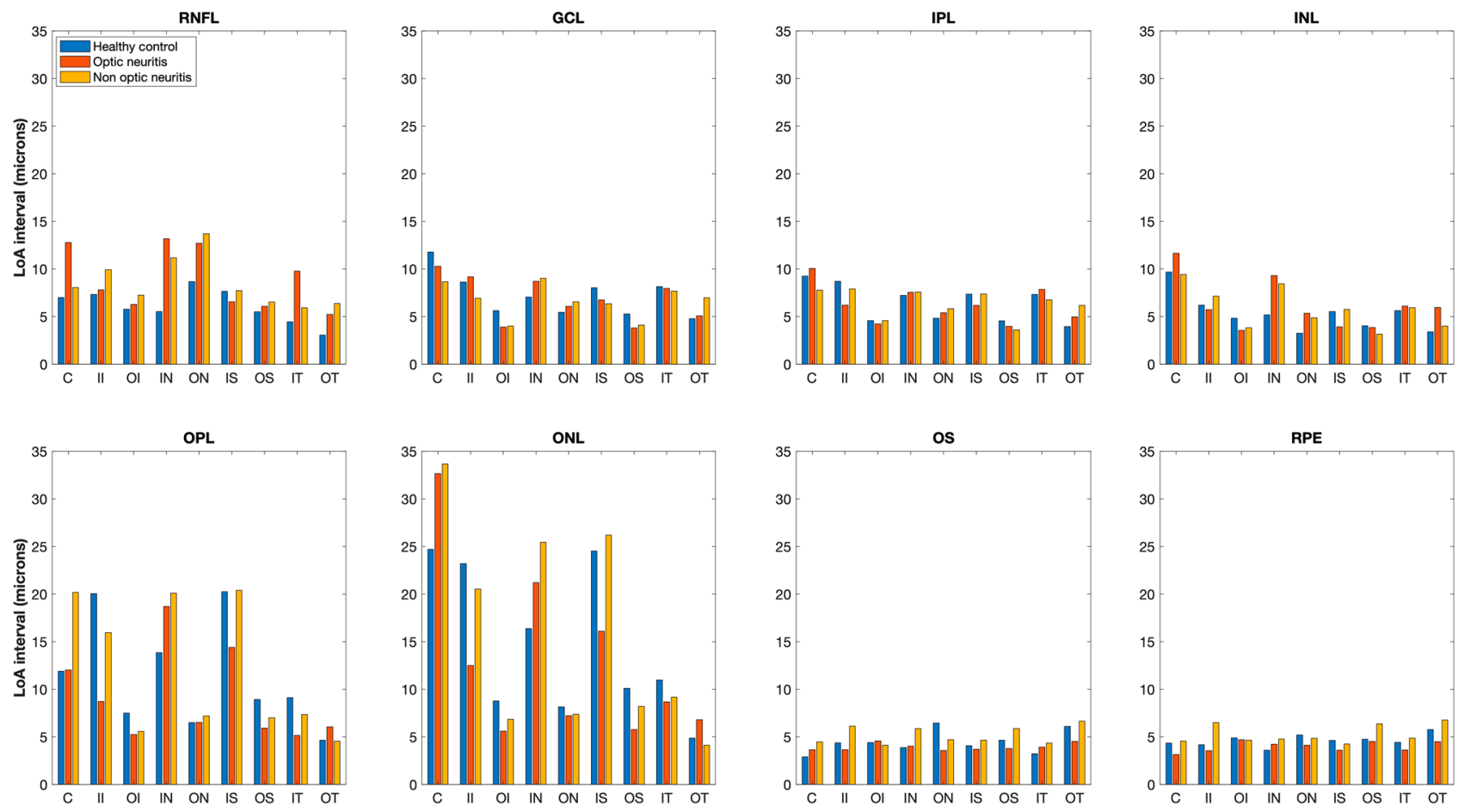

Figure 2. Limits of agreement (LoA) interval for eight layers in nine Early Treatment Diabetic Retinopathy Study sectors for the healthy controls (blue bars), eyes with optic neuritis (red bars), and fellow eyes without optic neuritis (orange bars). C central circle, II inner inferior, OI outer inferior, IN inner nasal, ON outer nasal, $I S$ inner superior, OS outer superior, IT inner temporal, OT outer temporal sectors, RNFL retinal nerve fiber layer, GCL ganglion cell layer, $I P L$ inner plexiform layer, $I N L$ inner nuclear layer, $O P L$ outer plexiform layer, $O N L$ outer nuclear layer, $O S$ outer segment, $R P E$ retinal pigment epithelium.

The LoA interval from the present results also showed that OPL and ONL in the central and inner sectors have the widest agreement interval in all 3 groups. A previous study evaluated the individual retinal layer thicknesses repeatability in nine ETDRS sectors with horizontal scans and showed worse repeatability for the inner sectors compared to the outer sectors in these layers ${ }^{5}$. It is known that if one method of measurement has poor repeatability, the agreement between the two methods will be poor. If both methods have poor repeatability, the agreement will be even worse ${ }^{25}$. The present results show larger LoA for the inner sectors, which is similar to the larger repeatability limits reported previously for the inner sectors ${ }^{5}$. Therefore, the presents results could be explained by the poor repeatability in these sectors.

The orientation of B-scan is shown to have an impact in the segmentation of individual retinal layers, in particular the delineation of OPL as the Henle's fiber layer visibility is dependent on the orientation of the $\operatorname{scan}^{28,29}$. Due to this, a vertical oriented B-scan is suggested to have a potential advantage over horizontally oriented B-scan. A previous study comparing vertical and horizontal macular scans in a smaller sample of healthy and multiple sclerosis subjects showed larger LoA interval for OPL and ONL compared to the other four layers (RNFL, GCL-IPL, OS and RPE) analyzed ${ }^{7}$. We also found similar results in the present study in all 3 groups where a sector-wise analysis was performed. Though changes in these layers are not a diagnostic biomarker in multiple sclerosis, transient changes can occur in the ONL following the onset of optic neuritis, which is shown to be a predictor on visual acuity outcome ${ }^{20}$. The ONL thickness is also an important quantitative measurement in other disease conditions like central serous chorioretinopathy ${ }^{30}$, inherited retinal disorders ${ }^{31,32}$, or history of prematurity ${ }^{33}$, where the present results should be considered. It would be interesting to evaluate different scan orientations in other ocular disorders as well. The present study did not include compensation for the magnification effect due to axial length differences. However, we believe that this will not have an impact on the present results as the comparison of the 2 different scan directions were performed on the same eye.

In conclusion, the mean differences between the horizontal and vertical macular volumetric scan modes to measure individual retinal layer thickness were smaller than the axial resolution of the instrument. However, the wide LoA interval obtained for different layers and sectors in HC, ON and NON groups, emphasizes the importance of using the same scan direction during follow-up visits and in clinical studies.

Received: 2 July 2021; Accepted: 28 December 2021

Published online: 12 January 2022 


\section{References}

1. Mwanza, J.-C. \& Budenz, D. L. New developments in optical coherence tomography imaging for glaucoma. Curr. Opin. Ophthalmol. 29, 121-129 (2018).

2. Sung, K. R. et al. Macular assessment using optical coherence tomography for glaucoma diagnosis. Br. J. Ophthalmol. 96, 1452-1455 (2012).

3. Castillo, M. M. et al. Optical coherence tomography for the monitoring of neovascular age-related macular degeneration: A systematic review. Ophthalmology 122, 399-406 (2015).

4. Petzold, A. et al. Optical coherence tomography in multiple sclerosis: A systematic review and meta-analysis. Lancet Neurol. 9, 921-932 (2010).

5. Zahavi, O., Domínguez-Vicent, A., Brautaset, R. \& Venkataraman, A. P. Evaluation of automated segmentation algorithm for macular volumetric measurements of eight individual retinal layer thickness. Appl. Sci. 11 (2021).

6. Kim, J. H. et al. Comparison of individual retinal layer thicknesses between highly myopic eyes and normal control eyes using retinal layer segmentation analysis. Sci. Rep. 9, 14000 (2019).

7. Gonzalez Caldito, N. et al. Analysis of agreement of retinal-layer thickness measures derived from the segmentation of horizontal and vertical spectralis OCT macular scans. Curr. Eye Res. 43, 415-423 (2018).

8. Matlach, J., Wagner, M., Malzahn, U. \& Gobel, W. Repeatability of peripapillary retinal nerve fiber layer and inner retinal thickness among two spectral domain optical coherence tomography devices. Invest. Ophthalmol. Vis. Sci. 55, 6536-6546 (2014).

9. Töteberg-Harms, M., Sturm, V., Knecht, P. B., Funk, J. \& Menke, M. N. Repeatability of nerve fiber layer thickness measurements in patients with glaucoma and without glaucoma using spectral-domain and time-domain OCT. Graefes Arch. Clin. Exp. Ophthalmol. 250, 279-287 (2012).

10. Domínguez-Vicent, A., Brautaset, R. \& Venkataraman, A. P. Repeatability of quantitative measurements of retinal layers with SDOCT and agreement between vertical and horizontal scan protocols in healthy eyes. PLoS ONE 14, e0221466-e0221466 (2019).

11. Ctori, I. \& Huntjens, B. Repeatability of foveal measurements using spectralis optical coherence tomography segmentation software. PLoS One 10, e0129005 (2015).

12. Mwanza, J.-C., Warren, J. L. \& Budenz, D. L. Utility of combining spectral domain optical coherence tomography structural parameters for the diagnosis of early Glaucoma: A mini-review. Eye Vis. (London, England) 5, 9 (2018).

13. Chen, T. C. et al. Spectral-domain OCT: Helping the clinician diagnose glaucoma: A report by the american academy of ophthalmology. Ophthalmology 125, 1817-1827 (2018).

14. Rabiolo, A. et al. Comparison of rates of progression of macular OCT measures in glaucoma. Transl. Vis. Sci. Technol. 9, 50 (2020),

15. Bussel, I. I., Wollstein, G. \& Schuman, J. S. OCT for glaucoma diagnosis, screening and detection of glaucoma progression. Br. J. Ophthalmol. 98(Suppl 2), ii15-9 (2014).

16. Saidha, S. et al. Optical coherence tomography reflects brain atrophy in multiple sclerosis: A four-year study. Ann. Neurol. 78, 801-813 (2015).

17. Birkeldh, U. et al. The temporal retinal nerve fiber layer thickness is the most important optical coherence tomography estimate in multiple sclerosis. Front. Neurol. 8, 675 (2017).

18. Bayhan, H. A., Aslan Bayhan, S., Tanık, N. \& Gürdal, C. The association of spectral-domain optical coherence tomography determined ganglion cell complex parameters and disease severity in Parkinson's disease. Curr. Eye Res. 39, 1117-1122 (2014).

19. Lee, J.-Y., Ahn, J., Kim, T. W. \& Jeon, B. S. Optical coherence tomography in Parkinson's disease: is the retina a biomarker?. J. Parkinsons. Dis. 4, 197-204 (2014).

20. Fard, M. A. et al. Photoreceptor outer nuclear layer thickness changes in optic neuritis follow up. Mult. Scler. Relat. Disord. 39, 101905 (2019).

21. Pierro, L., Gagliardi, M., Iuliano, L., Ambrosi, A. \& Bandello, F. Retinal nerve fiber layer thickness reproducibility using seven different OCT instruments. Invest. Ophthalmol. Vis. Sci. 53, 5912-5920 (2012).

22. Comyn, O. et al. Repeatability of Spectralis OCT measurements of macular thickness and volume in diabetic macular edema. Invest. Ophthalmol. Vis. Sci. 53, 7754-7759 (2012).

23. Liu, X. et al. Repeatability and reproducibility of eight macular intra-retinal layer thicknesses determined by an automated segmentation algorithm using two SD-OCT instruments. PLoS One 9, e87996 (2014).

24. Venkataraman, A. P., Andersson, J., Fivelsdal, L., Nilsson, M. \& Domínguez-Vicent, A. Impact of optical coherence tomography scan direction on the reliability of peripapillary retinal nerve fiber layer measurements. PLoS One 16, e0247670 (2021).

25. Bland, J. M. \& Altman, D. G. Measuring agreement in method comparison studies. Stat. Methods Med. Res. 8, 135-160 (1999).

26. Hu, H. et al. Focal thickness reduction of the ganglion cell-inner plexiform layer best discriminates prior optic neuritis in patients with multiple sclerosis. Invest. Ophthalmol. Vis. Sci. 60, 4257-4269 (2019).

27. Xu, S. C. et al. Optical coherence tomography is highly sensitive in detecting prior optic neuritis. Neurology 92, e527-e535 (2019).

28. Lujan, B. J., Roorda, A., Knighton, R. W. \& Carroll, J. Revealing Henle's fiber layer using spectral domain optical coherence tomography. Invest. Ophthalmol. Vis. Sci. 52, 1486-1492 (2011).

29. Mrejen, S., Gallego-Pinazo, R., Freund, K. B. \& Paques, M. Recognition of Henle's fiber layer on OCT images. Ophthalmology 120, e32-3.e1 (2013).

30. Yu, J. et al. The relationship between foveal outer nuclear layer thickness in the active and resolved phases of central serous chorioretinopathy treated with half-dose photodynamic therapy. BMC Ophthalmol. 19, 84 (2019).

31. Sousa, K., Fernandes, T., Gentil, R., Mendonça, L. \& Falcão, M. Outer retinal layers as predictors of visual acuity in retinitis pigmentosa: A cross-sectional study. Graefe's Arch. Clin. Exp. Ophthalmol. 257, 265-271 (2019).

32. Hood, D. C. et al. The inner segment/outer segment border seen on optical coherence tomography is less intense in patients with diminished cone function. Invest. Ophthalmol. Vis. Sci. 52, 9703-9709 (2011).

33. Sjöstrand, J., Rosén, R., Nilsson, M. \& Popovic, Z. arrested foveal development in preterm eyes: Thickening of the outer nuclear layer and structural redistribution within the fovea. Invest. Ophthalmol. Vis. Sci. 58, 4948-4958 (2017).

\section{Author contributions}

Each author is expected to have made substantial contributions to the conception or design of the work; or the acquisition, analysis, or interpretation of data; or the creation of new software used in the work; or have drafted the work or substantively revised it. A.D.V. and A.V. have conceptualized and designed the work, data acquisition and analysis, interpreted the data, and drafted the work. M.N. and R.B. interpreted the data, and revised the drafted work. All authors have approved the submitted version and have agreed both to be personally accountable for the author's own contributions and to ensure that questions related to the accuracy or integrity of any part of the work, even ones in which the author was not personally involved, are appropriately investigated, resolved, and the resolution documented in the literature. 


\section{Funding}

Open access funding provided by Karolinska Institute. The research was funded in part by promoting vision research fund (Ögonfonden) awarded to Alberto Domínguez-Vicent.

\section{Competing interests}

The authors declare no competing interests.

\section{Additional information}

Correspondence and requests for materials should be addressed to A.D.-V.

Reprints and permissions information is available at www.nature.com/reprints.

Publisher's note Springer Nature remains neutral with regard to jurisdictional claims in published maps and institutional affiliations.

(c) (i) Open Access This article is licensed under a Creative Commons Attribution 4.0 International License, which permits use, sharing, adaptation, distribution and reproduction in any medium or format, as long as you give appropriate credit to the original author(s) and the source, provide a link to the Creative Commons licence, and indicate if changes were made. The images or other third party material in this article are included in the article's Creative Commons licence, unless indicated otherwise in a credit line to the material. If material is not included in the article's Creative Commons licence and your intended use is not permitted by statutory regulation or exceeds the permitted use, you will need to obtain permission directly from the copyright holder. To view a copy of this licence, visit http://creativecommons.org/licenses/by/4.0/.

(C) The Author(s) 2022 